\title{
Does the Mundell-Fleming model fit in China?*
}

\author{
Kai-Hua Wang ${ }^{1}$, Chi-Wei Su ${ }^{2}$, Ran Tao ${ }^{3}$
}

\begin{abstract}
This paper examines the causal relationship between interest rate differential (IRD) and international short-term capital flow (SCF) to determine whether such a relationship in China supports the Mundell-Fleming model. With structural changes existing, we find that long-run relationship using full-sample data is unstable, suggesting that causality test is not reliable. Consequently, we use a time-varying rolling-window approach to revisiting the dynamic causal relationship, and the results show that IRD has both positive and negative impacts on SCF in several sub-periods, but SCF has no effect on IRD in China. When China suffers external and internal shocks, SCF should not be curbed only by adjusting IRD. Therefore, it is critical for policymakers to pay attention to specific backgrounds (e.g. economic situation, monetary policies) and further employ interest rate and fiscal policies in reducing negative influence from SCF on the Chinese economy.
\end{abstract}

Key words: Mundell-Fleming model, short-term capital flow, interest rate differential, rolling window, time-varying causality

JEL classification: C32, F32, G18

\footnotetext{
* Received: 06-06-2018; accepted: 20-02-2019

1 Assistant Professor, Qingdao University-School of Economics, 308 Ningxia Road, Qingdao, Shandong, China. Scientific affiliation: international finance and risk management. Phone: +86 15762285927.E-mail:937276847@qq.com.

2 Full Professor, Qingdao University-School of Economics, No. 308 Ningxia Road, Qingdao, Shandong, China. Corresponding author. Scientific affiliation: time series analysis, international finance and risk management. Phone: +86 18661491158.E-mail: cwsu7137@gmail.com.

3 Engineer, Department of Noninfectious Chronic Disease, Qingdao Municipal Center for Disease Control \& Preventation, No. 175 Shandong Road, Qingdao, Shandong, China. Scientific affiliation: international finance and economic modeling. Phone: +8615165252618. E-mail:taotao0212@163.com.
} 


\section{Introduction}

The objective of this paper is to test the causal relationship between interest rate differential (IRD) and international short-term capital flow (SCF) and whether the Mundell-Fleming model fits for China. SCF refers to the flow of speculative (or capital) from one country to another in order to earn a short-term profit on IRD and/ or anticipated exchange rate shifts (Chari and Kehoe, 2003). From the standpoint of the Mundell-Fleming model, a long-run relationship between IRD and SCF represents unity. IRD across countries should be an unbiased predictor of SCF and a higher domestic interest rate would attract foreign capital inflow (Kim, 2007). Emerging markets (e.g. China) have weaker macroeconomic fundamentals (e.g. more volatile economic conditions, shallower financial markets, and incomplete institutional reforms) that make it more vulnerable to SCF shocks. Since SCF has gradually become an important part of the international capital flow in China in a decade, the volatility of SCF may affect the development of Chinese economy severely. A large amount of international capital inflowing to Chinese economy puts pressure on inflation and asset price boom, which makes its economy fluctuates widely. Oppositely, massive outflows would drain needed resources from development projects, which as a result put pressure on monetary and exchange rate policies (Cheung, 2016).

The financial crisis of 2008 has had a significant negative impact on the Chinese economy, affecting exports, foreign exchange reserves and structural adjustments. To keep economic stability and continue the momentum of rapid development, the (People's Bank of China) PBOC has implemented a moderately low-interest policy starting with the end of 2008. Nevertheless, China's low its interest rate remained higher than U.S.'s, Japan's and Eurozone's. Wang et al. (2016) indicate that in recent years China has implemented a moderate interest policy to reduce the fluctuation of SCF, which has proven uneffective. Consequently, there is imminent concern regarding how the interest rate policy would bring substantial SCF for China. According to Hacker et al. (2014), the Mundell-Fleming model stresses out the idea that international capital would flow when facing a constant domesticforeign interest differential. If the Mundell-Fleming model fits for China, the higher domestic interest rate would trigger international capital inflows. In response to this, we are greatly motivated to pursue an investigation related to the relationship between IRD and SCF in China.

The major contribution of our work is to employ bootstrap rolling-window method to investigate the time varying character in the relationship between IRD and SCF. This method is different from previous ones (e.g. pulse impulse response) which cannot distinguish full-sample and sub-sample relationship changes over time. Empirical studies verify that causality between two-time series may lead to inaccurate results when the underlying full-sample time series have structural 
changes (Balcilar and Ozdemir, 2013). This can be addressed by allowing the casual relationship between the two series to be time varying instead of using full-sample data that assume the single causality holds in every time period. The time-varying character that may exist in the causal link between IRD and SCF has been taken fully into consideration in this paper. Depending on this approach, it shows that there are unidirectional causal links between IRD and SCF with sub-sample rollingwindow estimation. IRD has had both positive and negative impact on SCF in several sub-periods. Meanwhile, SCF has had no effect on IRD. When external and internal shocks are being suffered, IRD cannot fully explain the reasons for SCF. Therefore, it is critical for policymakers to pay attention to specific backgrounds (e.g. economic situation, monetary policies) and further make use of interest rate and fiscal policies to reduce negative influence from SCF on the Chinese economy. Hence, the main hypothesis of this paper is that the relationship between IRD and SCF is changing over time, and the Mundell-Fleming model is not always hold.

This paper proceeds as follow. Section 2 presents literature review for the relationship between SCF and IRD. Section 3 shows Mundell-Fleming model and bootstrap rolling-window causality test. Section 4 provides empirical data and analyze time-varying link between SCF and IRD. Section 5 indicates MundellFleming model does not always hold and find corresponding potential reasons. Section 6 demonstrates conclusions and offers policy implications.

\section{Literature review}

Substantial studies have been undertaken to focus on the relationship between IRD and SCF over the past century. Mundell (1960) puts forward the investment-saving, liquidity preference-money supply and balance of payments (IS-LM-BP) model and regards capital as a function of IRD. He also indicates that IRD can bring a continuous capital flow. Fleming (1962) indicates that the SCF is more sensitive to floating interest rate than fixed interest rate. Aizenman and Hutchison (2012) find that interest rate plays a major role in large flows of capital across borders of emerging market economies. Ahmed and Zlate (2014) find growth and interest rate differentials between emerging market economies and advanced economies and global risk appetite are statistically and economically important determinants of net private capital inflows. Globan et al. (2015) propose higher interest rate in the Eurozone vis-à-vis the host economies should negatively impact capital flows to non-eurozone European Union new member states. Carvalho and Fidora (2015) find capital flows into the euro area were particularly large in the mid-2000s, which is associated with a reduction of euro area long-term interest rates. Makhetha-Kosi et al. (2016) discover that the positive interest rate differential in South Africa did not translate to proportionately higher capital inflows. Ning et al. (2017) indicate emerging market economies lost a large amount of capital, which result from the 
recovery of the U.S. economy and the exit of the Federal Reserve from quantitative easing policies, such as the rise of the U.S. interest rate.

In the context of globalisation and internationalisation, China has become a key destination for SCF. In consequence, China has gradually started paying attention to the resulting effects this has had on its economy. At the same time, China's interest rate liberalization is carried out. Therefore, the link between capital flow and interest rate has also been investigated in previous studies, but Literature further reflects lack of consensus in this regard. Hu (2013) investigates China's SCF's the relationship and find a positive correlation relation between capital market interest rates and short-term capital flows. Wang et al. (2016) indicate that in responsible to the wide interest rate spreads, a considerable international capital has flown into China in recent years, largely in making arbitrage profits in China. Ning and Zhang (2017) show that downward pressure on the Chinese economy and the Renminbi (RMB) brings capital outflow, while the rise of the US interest rate renders the US a safe home for investors under global risks.

Even though many studies have investigated the relationship between SCF and IRD, but the time-varying character that the relationship between SCF and IRD may be changed under certain background is not taken into account, which may result in inaccurate conclusion. Therefore, this paper employ bootstrap rollingwindow causality test to capture the structural breaks in the relationship, prove the nonlinear relationship under different backgrounds and give corresponding reasons under certain situation.

\section{Methodology}

With the purpose of analyzing the relationship between IRD and SCF, the MundellFleming Model provides theoretical basis for this study.

\subsection{Mundell-Fleming model}

In the 1960s, Mundell (1960) and Fleming (1962) analyse SCF under different exchange rate regimes built IS-LM-BP frame system. This model assumes capital flow is a function of domestic and international spread if two countries have IRD, which can result in international capital flowing into higher interest rate country. We use the two-country model to analyse the relationship between IRD and SCF. We choose $A$ and $B$ present domestic and foreign country separately. $\Delta F_{A}$ presents the SCF from $B$ to $A$. $I_{A}$ presents the capital flow without influence from IRD. $f_{A}$ presents $\mathrm{SCF}$ is influenced by IRD. This is expressed as:

$$
\Delta F_{A}=I_{A}+f_{A}\left(R_{A}, R_{B}\right)
$$


where $f_{A}$ is positive with $R_{A}, f_{A}$ is negative with $R_{B}$, which means that $\partial f_{A} / \partial R_{A}>0$, $\partial f_{A} / \partial R_{A}<0$. Therefore, we simplify the equation to the following:

$$
\Delta F_{A}=I_{A}+f_{A}\left(R_{A B}\right)
$$

where $R_{A B}=R_{A}-R_{B}$ and $\partial f_{A} / \partial R_{A B}>0$, which means the capital flow is positive with IRD. When the domestic interest is lower than the interest rate in the rest of the world, capital flows out of the country until the two interest rates become equal again.

\subsection{Bootstrap rolling-window causality test}

This section offers fresh evidence from methodological aspect. It focuses on the stability of parameter in VAR model and provide convincing empirical results.

\subsubsection{Bootstrap full-sample causality test}

Shukur and Mantalos (2004) indicate that as a result of using the residual-based bootstrap (RB) method, critical values are improved in power and size. Moreover, the excellent performance of the RB method over standard asymptotic tests, regardless of cointegration, in a vast number of Monte Carlo simulation studies has been positively verified (Balcilar et al., 2010). In particular, Shukur and Mantalos (2000) prove that small sample corrected likelihood ratio (LR) tests display a relatively improved properties such as power and size, regardless of the dimennsion of the samples-including small ones. Such results point out that should the cointegration be absent, all standard tests not making use of the RB method would perform inadequately, particularly in those small samples. As a consequence, this article resorts to the option of the RB-based modified-LR statistic to examine causality between IRD and SCF. To show the RB-based modified-LR causality test, the bivariate vector autoregression (VAR) process is considered as follows:

$$
\left[\begin{array}{l}
I R D_{1 t} \\
S C F_{2 t}
\end{array}\right]=\left[\begin{array}{c}
\varphi_{10} \\
\varphi_{20}
\end{array}\right]+\left[\begin{array}{l}
\varphi_{11}(L) \varphi_{12}(L) \\
\varphi_{21}(L) \varphi_{22}(L)
\end{array}\right]\left[\begin{array}{l}
I R D_{1 t} \\
S C F_{2 t}
\end{array}\right]+\left[\begin{array}{l}
\varepsilon_{1 t} \\
\varepsilon_{2 t}
\end{array}\right], t=1,2 \ldots T
$$

where $\varepsilon_{t}=\left(\varepsilon_{1 t}, \varepsilon_{2 t}\right)^{\prime}$ is a zero mean, independent, white noise process with nonsingular covariance matrix $\Sigma$. The optimal lag length $p$ is determined by the Schwarz Information Criteria (SIC) in this paper. $\phi i j(L)=\Sigma_{k=1}^{p+1} \phi_{i j, k} L^{k}, i, j=1$, 2 and $\mathrm{L}$ is the lag operator defined as $L^{k} X_{t}=X_{t-k}$. Based on the Equation (3), the null hypothesis that SCF does not Granger cause IRD is tested by imposing the restriction, $\varphi_{12, k}=0$ for $k=1,2 \ldots p$. Similarly, the null hypothesis that SCF does not Granger cause IRD is tested by imposing the restriction, $\varphi_{21, k}=0$ for $k=1,2 \ldots$ $p$. As previously debated, the tests of full sample causality applied in this paper rely on RB-based $p$-values and modified-LR statistic. If the first null hypothesis 
$\varphi_{12, k}=0$ for $k=1,2 \ldots p$ is rejected, there is a significant causality running from IRD to SCF. This means IRD can predict movements in inflation. Similarly, if the second null hypothesis $\varphi_{21, k}=0$ for $k=1,2 \ldots p$ is rejected, IRD is caused by movements in SCF.

\subsubsection{Parameter stability test}

The full-sample causality tests usually assume that the parameter of the VAR model used in testing is constant over time. However, when the underlying fullsample time exhibits structural changes, the assumption is likely violated. The results from the full-sample causality tests become invalid, and hence, the causal links between series show instability (Balcilar and Ozdemir, 2013). Hence, Sup-F, Mean-F, and Exp-F tests (Andrews, 1993; Andrews and Ploberger, 1994) are used to investigate short-run parameter stability. Regardless, it has been pinned down the fact that when underlying variables are cointegrated in levels, the first difference in the VAR model is wrongly specified unless it allows for error correction. Hence, it is essential to test for the cointegration and parameter stability of the long-run relationship. In the present paper, the $L_{c}$ test proposed by Nyblom (1989) and Hansen (1992) is applied to check the stability of long-run parameters.

These tests are calculated from the sequence of LR statistics that check the stability of the parameter against the provided substitute of a unique structural break at an unknown time. Since these tests exhibit non-standard asymptotic distributions, critical values and $p$-values are proposed by means of the parametric bootstrap procedure (Andrews and Ploberger, 1994). Andrews (1993) also points that statistics require 15 percent trimming from both ends of the sample to test the stability of parameters in the short-run, the fraction of the sample in $(0.15,0.85)$ is needed. The $L_{c}$ tests are conducted in the current paper for the equations and VAR system separately by applying the FM-OLS estimator.

\subsubsection{Sub-sample rolling-window causality test}

Following Balcilar et al. (2010), the rolling-window technique is grounded on fixed-size sub-samples rolling unceasingly from start to end of the full sample. In particular, when given a fixed-size rolling window including $m$ observations, the full sample is transformed into a sequence of $T-m$ sub-samples. That is, $\tau-m+1$, $\tau-m, \ldots, T$ for $\tau=m, m+1, \ldots, T$. Then, it can apply the RB-based modifiedLR causality test to each sub-sample, instead of estimating a single causality test for a full sample. Possible changes in the causal links between IRD and SCF are intuitively identified by calculating the bootstrap $p$-values of observed LR statistics rolling through T-m sub-samples. The influence of IRD on SCF is defined as the average of the entire bootstrap estimates derived from the formula $N_{b}^{-1} \Sigma_{k=1}^{p} \phi_{21, k}^{*}$, with $N_{b}$ representing the number of bootstrap repetitions; similarly, 
the influence of SCF on IRD is obtained from the formula $N_{b}^{-1} \Sigma_{k=1}^{p} \phi_{12, k}^{*}$. Both $\phi_{21, k}^{*}$ and $\phi_{12, k}^{*}$ are bootstrap estimates from the VAR models in Equation (3). The $90 \%$ confidence intervals are also computed, for which the lower and upper limits equal the 5th and 95th quantiles of each of the $\phi^{*}{ }_{21, k}$ and $\phi_{12, k}^{*}$, respectively (Balcilar et al., 2010).

There are two conflicting objectives in the rolling-window estimation that accuracy of the parameter estimates and the representativeness of the model over the subsample period. A large window size may improve the accuracy of the estimate but may reduce the representativeness in the presence of heterogeneity. On the contrary, a small one may improve the representativeness and reduce accuracy. Consequently, we must select a suitable number of observations to balance the trade-off between representativeness and accuracy. Pesaran and Timmerman (2005) demonstrate that optimal window size depends on persistence and size of the break and they use Monte Carlo simulations to show that the minimum limit is 20 observations. Taking it and the two conflicting demands, we choose 24 months as the optimal selection in this paper.

\section{Empirical data and analysis}

We use the monthly data covering the period from 2007: M01 to 2016: M09 because this includes the U.S. subprime crisis in 2007 which spreads the whole world rapidly, the Chinese economy being in the doldrums and the lack of effective market demand from outside. To maintain economic stability, the PBOC increases the supply of money, and this has a great effect on domestic interest rate level (Glick and Hutchison, 2009). Furthermore, the appropriate policy response to capital inflows may be lower interest rate (Kumhof, 2004). First, we use one-year maturity dollar London Interbank Offered Rate (LIBOR) for the foreign interest rate (Tamakoshi and Hamori, 2014) and we extract the data from Thomson Reuters Datastream. Second, we use one-year maturity Shanghai Interbank Offered Rate (SHIBOR) for the domestic interest rate, and the data are taken from the PBOC (Gu et al., 2014). Third, we acquire SCF from the National Bureau of Statistics of China and we also adjust for seasonal trends within original series. IRD is used to measure changes in the interest spread level between home and abroad. Similarly, SCF is used to measure changes in the fluctuation of international capital flow. 
Figure 1: Growth Rate of IRD and SCF

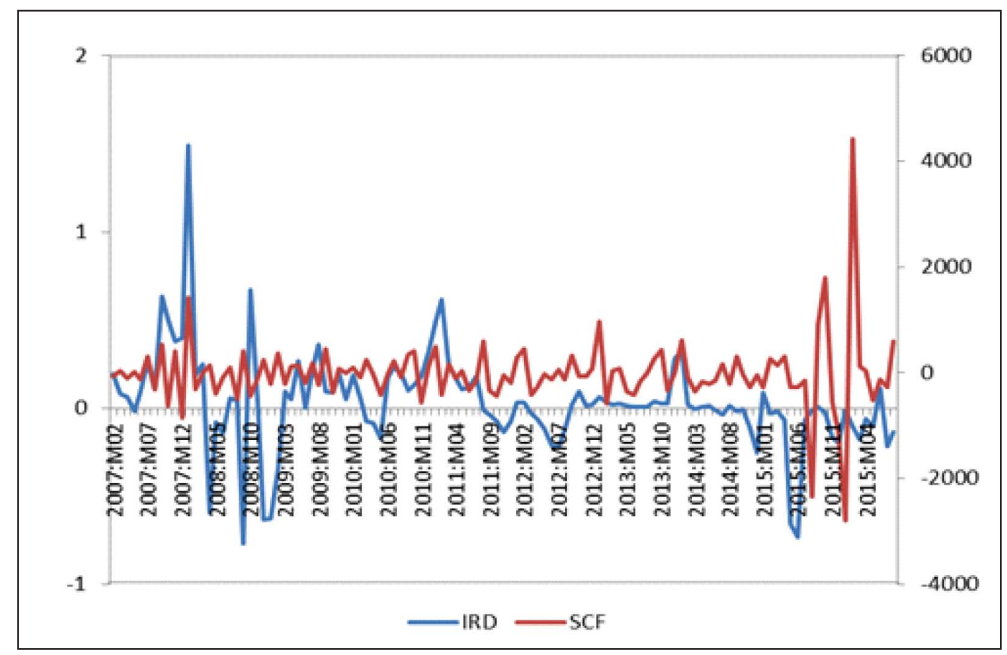

Source: Author's calculations

Figure 1 indicates that IRD and SCF have the same trend and several significant changes. The IRD increases in the period 2007:M02-2007:M12, 2008:M062008:M10, 2009:M01-2009:M08 and 2010:M08-2011:M01. In the first subinterval, a subprime crisis breaks out in U.S. and 50 bp rate cut in the Federal funds rate, which lowers international interest rate. In the second sub-interval, Fannie Mae and Freddie Mac, the top two largest U.S. real estate companies, are taken over by the U.S. government and Lehman Brothers file for bankruptcy protection that sparks market panic and brings interest rate down. In the third sub-interval, Federal funds rate is cut to the area from $0 \%$ to $0.25 \%$ and unemployment rate reaches highest since 1983 in U.S., which shows uncertainty for the investors and brings the interest rate down. In the last sub-interval, the central Bank of Japan cuts its interest rate to $0.1 \%$, and Federal Reserve begins the second round of quantitative easing policy, which contributes IRD become bigger. The IRD decreases in the period 2008:M01-2008:M05，2008:M11-2008:M12，2009:M09-2010:M07， 2011:M022012:M08, 2012:M09-2012:M11 and 2015:M06-2015:07.

In the first sub-interval, snowstorm and earthquake hit China and results in huge losses. At the same time, China suffers a serious stock market crash that the Chinese Shanghai Stock Exchange Composite Index (SSECI) slumps from 5522 points to 2000 points, which has a negative influence on the Chinese economy. In the second sub-interval, the central government in China carries out "four trillion economic stimulus plan" to encounter the financial crisis, which brings adequate liquidity and brings the domestic interest rate down. In the third sub-interval, U.S. macroeconomic shows better than expected, which recovers investors' confidence 
and evaluate interest rate level. In the fourth sub-interval, the PBOC cuts interest rate to $3 \%$, which narrows IRD. The last sub-interval, the PBOC cuts one-year deposit interest rate to $1.6 \%$, which further narrows IRD. By comparing the shocks and trends in IRD and SCF, we find that these two variables are not always changed in the same direction and the relationship is complicated.We use the VAR model to test the full-sample causal relationship between IRD and SCF. The bivariate VAR models are the IRD and SCF and are constructed as in Equation (3). Upon examination, the optimal lag length based on Akaike Information Criterion (AIC) of IRD and SCF is 4. The full-sample causality results based on the RB-based modified-LR causality tests are reported in Table 1. According to the bootstrap $p$-values, IRD does Granger cause SCF, but SCF does not Granger cause IRD. This finding is consistent with some of the existing literature (Ayanou; 2016) and IRD has a positive unidirectional effect on SCF.

Table 1: Full-sample Granger-cause Tests

\begin{tabular}{|c|c|c|c|c|}
\hline & \multicolumn{3}{|c|}{$\mathrm{H}_{0}$ : IRD does not Granger cause SCF } & \multicolumn{2}{|c|}{$\mathrm{H}_{0}$ : SCF does not Granger cause IRD } \\
\hline & Statistics & $p$-value & Statistics & $p$-value \\
\hline LR test & $14.155^{* * *}$ & 0.010 & 7.056 & 0.105 \\
\hline
\end{tabular}

Note: ${ }^{* * *}$ Denotes significance at the $1 \%$ level.

Source: Authors' calculation

However, there is a default assumption in the previous literature that in time series structural changes do not exist and there is only a single causal relationship across the whole sample period (Balcilar et al., 2013). In the presence of structural changes, the parameters in the above VAR model estimated using full-sample IRD and SCF will shift with time. Therefore, the full-sample tests considering the assumptions of parameter constancy with a single causal relationship in the whole sample period being no longer reliable and therefore the results that follow are proven to carry no significant weight to them (Zeileis et al., 2005). Due to this reason, the present paper continues to test for parameter stability and pursues the purpose of confirming or denying the existence of structural changes. As previously mentioned, we make use of the Sup-F, Mean-F and Exp-F tests which have been created by Andrews and Ploberger (1994) to investigate the temporal stability of parameters in the above VAR model formed by IRD and SCF. Nyblom's (1989) and Hansen's (1992) $L_{c}$ test has also been employed hereby in testing for all parameters in the overall VAR system. The corresponding results are reported in Table 2. The Sup- $F$ tests under the null hypothesis of parameter constancy against a one-time sharp shift in parameters are reported in the first row. The conclusion shows that a one-time sharp shift exist in the IRD, SCF and VAR system at the $1 \%$ level. The Mean-F and Exp-F tests which have been run under the null hypothesis, where 
parameters pursue a martingale process, is completely opposing the possibility of parameters gradually evolving, an option which is reported in the second and third rows, respectively. $L_{c}$ statistics test opposite to the alternative of parameters following a random walk process, a proposal advanced by Gardner (1969), which is indicative of parameter non-constancy in the overall VAR model estimated.

Table 2: Parameter Stability Tests

\begin{tabular}{|l|c|c|c|c|c|c|}
\hline & \multicolumn{2}{|c|}{ IRD Equation } & \multicolumn{2}{c|}{ SCF Equation } & \multicolumn{2}{c|}{ VAR System } \\
\hline & Statistics & $p$-value & Statistics & $p$-value & Statistics & $p$-value \\
\hline Sup $-F$ & $197.20^{* * *}$ & 0.000 & $121.580^{* * *}$ & 0.000 & $105.091^{* * *}$ & 0.000 \\
\hline Mean $-F$ & $22.503^{* * *}$ & 0.000 & $63.072^{* * *}$ & 0.000 & $63.729^{* * *}$ & 0.000 \\
\hline Exp $-F$ & $94.586^{* * *}$ & 0.000 & $63.072^{* * *}$ & 0.000 & $49.514^{* * *}$ & 0.000 \\
\hline$L_{c}$ & & & & & $9.514^{* * *}$ & 0.005 \\
\hline
\end{tabular}

Note: We calculate $p$-values using 10,000 bootstrap repetitions. Hansen-Nyblom Parameter stability test for all parameters in the VAR jointly. ${ }^{* * *}$ Denotes significance at the $1 \%$ and $5 \%$ level, separately.

Source: Authors' calculation

Based on the above parameter stability tests, we can conclude that the model estimated using full-sample data are unstable because of the presence of structural changes. This further indicates that the causality between IRD and SCF is not credible in the full sample period. To take structural changes into account, we employ rollingwindow estimation to test the causal relationship between IRD and SCF; unlike the full-sample causality test, this approach tests the causal relationship between two variables more accurately for the reason of time varying across different sub-samples. In the sub-sample causality test of the rolling window, we use the RB bootstrapbased modified-LR causality test to check the causal relationship between IRD and SCF. The null hypothesis of the tests indicates that IRD does not Granger cause SCF and vice versa. The bootstrap $p$-values of LR statistics can be estimated from the VAR models in Equation (3) using the rolling sub-sample data including 24-month observations. After trimming 24-month ${ }^{4}$ observations from the beginning of the null sample, these rolling estimates move from 2009:M01 to 2016:M08.

Figure 2 shows that the null hypothesis that IRD does not Granger cause SCF is rejected at the $10 \%$ significance level in several sub-sample periods, including 2012:M03-2012:M08, 2015:M01-2015:M06 and 2015:M07-2016:M04.

$\overline{4}$ We wonder whether the results are sensitive to the choice of window size. Thus, we select different window sizes (e.g. 12, 24 and 36 months) to test and find the results are affected, but very little. 
Figure 2: Bootstrap $p$-value of rolling test statistic testing the null that IRD does not Granger cause SCF

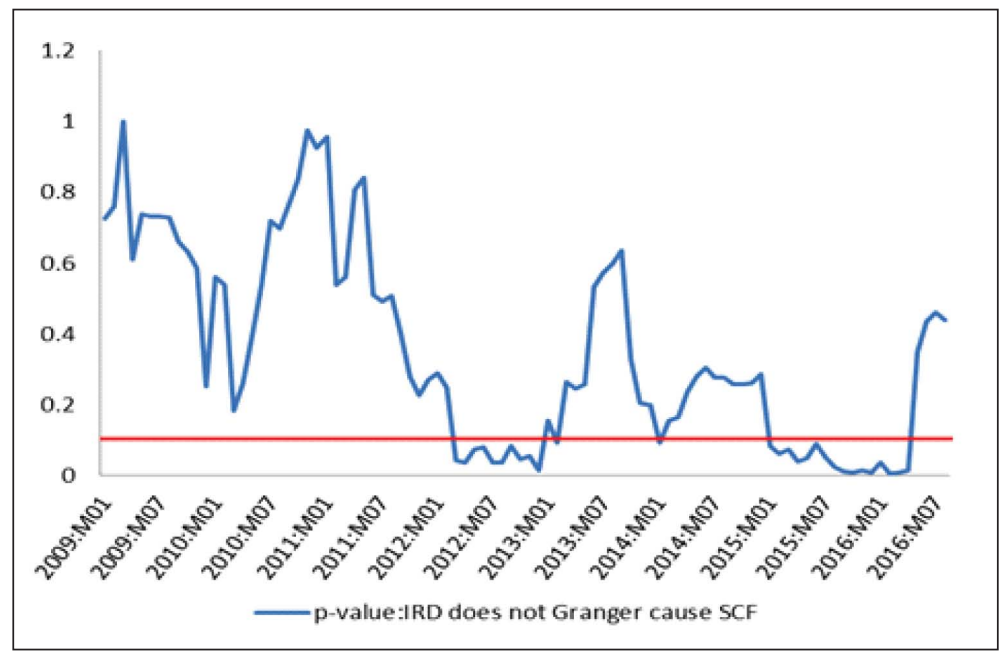

Source: Author's calculations

Figure 3: Bootstrap estimates of the sum of the rolling window coefficients for the impact of IRD on SCF

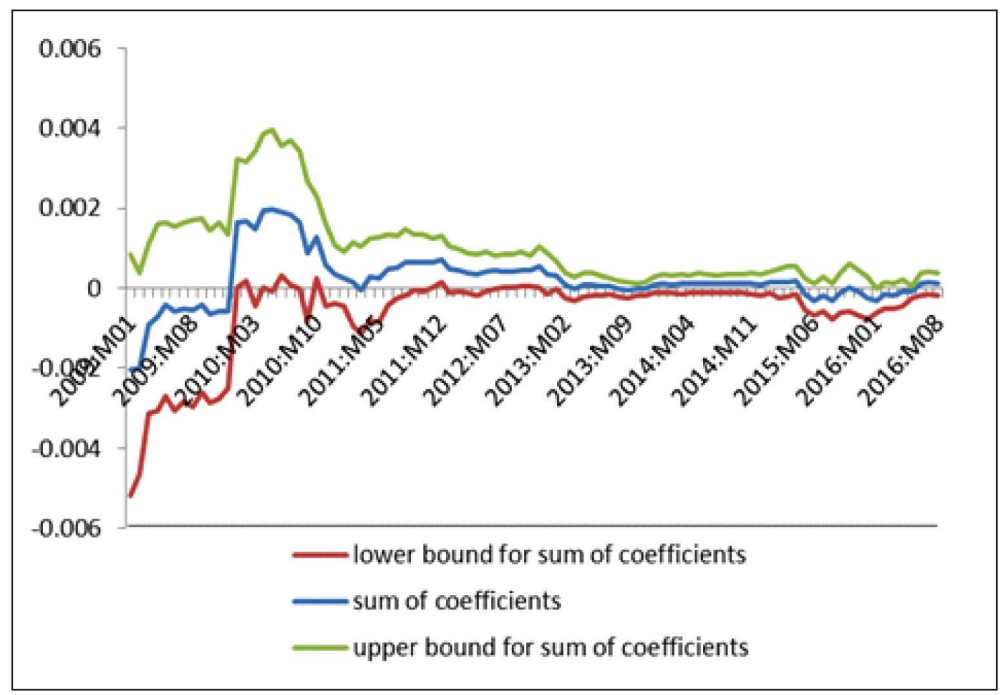

Source: Author's calculations

Figure 3 shows that in 2012:M03-2012:M08 and 2015:M01-2015:M06, IRD has a positive impact on SCF, while in 2015:M07-2016:M04, IRD has a negative impact on SCF. As we can see from Figure 1, in the period 2012:M03-2012:M08 and 
2015:M01-2015:M06, IRD decreases significantly and this change has a positive impact on SCF, which is consistent with Mundell-Fleming model (Mundell, 1960; Fleming, 1962). In the first period, The PBOC reduces deposit reserve ratio by $0.5 \%$ in February and May in 2012, separately. Meanwhile, the PBOC also reduces the benchmark of Renminbi deposit and lending rate of financial institutions by $0.5 \%$ and $0.56 \%$, separately. The falling interest rate reduces arbitrage opportunity, thus SCF decreases obviously. Besides, oil price reaches the highest level since the global financial crisis. With the increasing international oil price causing such results in the total amount of net exports and determining a decline of the real output, ripping further into a price ascension influences investors' confidence in Chinese economy will convey the result of a decreasing SCF. In the second interval, the $\mathrm{PBOC}$ reduces the deposit reserve ratio of financial institutions by $1.5 \%$, and in particular, the deposit reserve ratio for Agricultural Development Bank of China is cut from $13.5 \%$ to $10.5 \%$, which further narrows the interest spread at home and abroad and reduces arbitrage opportunity. In the period 2015: M07-2016:M04, IRD increases obviously, and this change has a negative impact on SCF. In this period, the SSECI plunged by $32 \%$, wiping out more than Renminbi 18 trillion in share value, which equals to about $30 \%$ of China's GDP in 2014 and has a negative influence on Chinese economy (Mensi et al., 2016). Meanwhile, IMF raises forecast of GDP growth in U.S. and indicates Federal Reserve would raise the interest rate, which pushes capital flows out of China. Besides, Ning et al. (2017) further explain that serious financial friction and information incompleteness of financial markets in China also result in inconsistency between the two variables.

However, in the period 2008:M01-2012:M03, 2012:M09-2014:M12 and 2016:M05-2016:M08, IRD has no significant impact on SCF, which is mainly because other factors exceed IRD to become the main reason that influences SCF. In the first sub-interval, Federal Reserve implements four times of quantitative easing policies separately in 2008, 2010 and twice in 2012, which weaken the U.S. dollar and stimulate capital outflows to emerging economies (Wang et al., 2016). Cheung et al. (2016) further notice that the wild fluctuation of capital inflows after the global financial crisis is mainly contributed to quantitative easing policies. In the second interval, over-inflows of international speculative capital contribute to the real estate prices rise rapidly, and boost the real estate bubble. Therefore, the central government in China implements the most stringent real estate policy, which stabilises housing prices and pushes part of SCF out of China. At the same time, Federal Reserve begins to withdraw from the quantitative easing policies and Federal Reserve's funds rate are expected to increase from the estimated $0 \%$, making East Asian countries (e.g. China) face capital outflow and put pressure on their own interest rate (Ogawa and Wang, 2016). In the third sub-interval, China's GDP growth rate is $6.7 \%$ in the second quarter that reach the lowest in recent years. Low GDP growth would reduce employment, consumption and international trade, which further decreases SCF. Meanwhile, Britain's departure from the European 
Union led to global concerns that Britain's economy will suffer a recession, which pushes SCF to more secure countries (e.g. U.S.). In general, the bootstrap subsample rolling estimates in Figure 2 indicate that the Mundell-Fleming model fits for China in the period of 2012:M03-2012:M11 and 2015:M01-2015:M05. However, in the period of 2015:M07-2016:M04, IRD has a negative impact on SCF under the internal and external shocks.

Figure 4: Bootstrap $p$-value of rolling test statistic testing the null that IRD does not Granger cause SCF

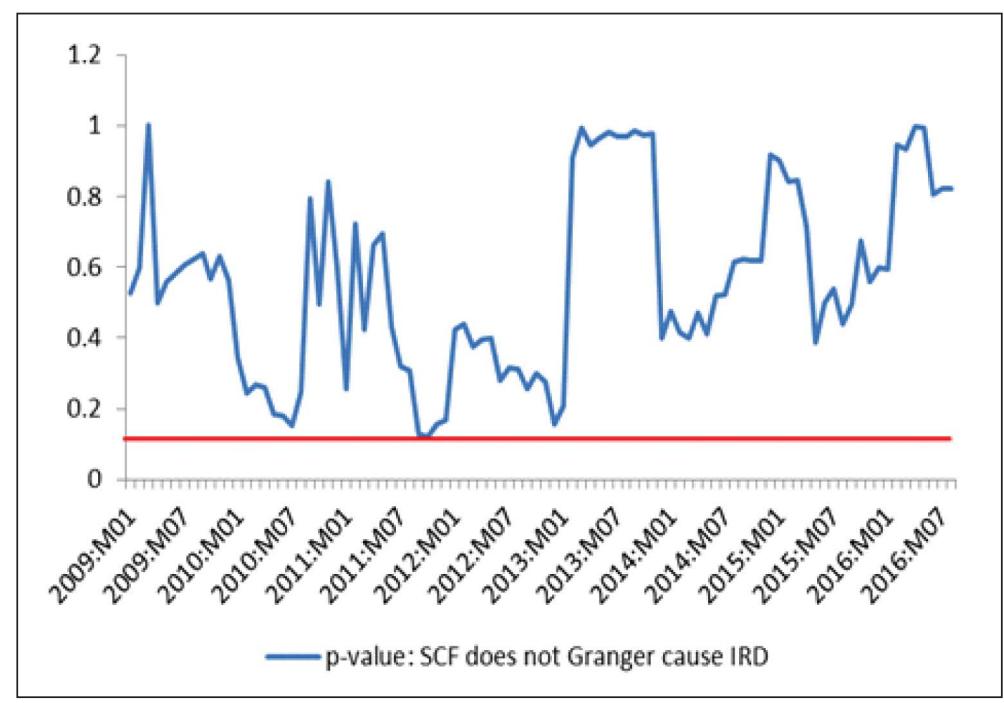

Source: Author's calculations

Figure 4 reports the rolling bootstrap $p$-values of the LR statistics with the null hypothesis that SCF does not Granger cause IRD. According to Figure 4, we can clearly see that the null hypothesis cannot be rejected significantly in the full sample period, which shows that SCF has no influence on IRD. This phenomenon can be contributed to following reasons: first, Glick and Hutchison (2009) indicate that China places a higher priority on exchange rate stability than using monetary policy as a tool for macroeconomic control, which results in China's scope for an autonomous monetary policy is constrained. Second, Chinese capital control policy plays a role in protecting domestic financial environment from external shocks by restricting the entry of foreign financial institutions and by making it harder for capital to flow out of the country. Cheung et al. (2016) also indicate that China has been adjusting its capital control policy to maintain a stable economic environment. Thus, SCF has no significant influence on the PBOC's monetary policy (e.g. interest rate policy). 


\section{Results and discussion}

In this paper, the bootstrap Granger full-sample causality test and sub-sample rolling-window estimation provide additional insight into the dynamic relationship between IRD and SCF in China. The previous studies ignore structural changes in time series and provide the default assumption that there is a linear nexus between two variables. However, structural changes always exist, and the parameters in the above VAR model estimated using full-sample IRD and SCF may not be constant. Hence, the full-sample tests considering the assumptions of parameter constancy with a single causal relationship in the whole sample period being no longer reliable and therefore the results that follow are proven to carry no significant weight to them (Zeileis et al., 2005). Due to this reason, the present paper continues to test for parameter stability and pursues the purpose of confirming or denying the existence of structural changes. As previously mentioned, we make use of the Sup-F, Mean-F and Exp-F tests which have been created by Andrews and Ploberger (1994) to investigate the temporal stability of parameters in the above VAR model formed by IRD and SCF. The empirical results show that the link between IRD and SCF is not always consistent with the view that SCF changes with IRD in the same direction. It can support the Mundell-Fleming model in the period of 2012:M03-2012:M11 and 2015:M01-2015:M05. However, in other periods, we cannot get the same conclusion. The relationship between IRD and SCF in China is not stable over time and even shows a short-term deviation from the positive link. It is actually suitable as in the past few decades China experiences domestic economic restructuring and global economic fluctuation, which result in structural changes in monetary policy. Since the financial crisis in 2007, there has been a significant influence on Chinese economic environment between home and abroad. Mensi et al. (2016) show that significant time-varying correlation and several structural changes exist between the U.S. and Brazil, Russia, India, China and South Africa (BRICS) stock markets. More than a decade ago, China begins its interest rate liberalization and China has removed the interest ceiling of deposit rates and enters the final stage of interest rate liberalization. In 2015, the Central Economic Working Conference proposes the supply-side structural reforms, which could be regarded as the major strategic innovations that adapt to and lead China's New Normal Status. All these internal and external events may have a temporary impact on the relationship between IRD and SCF in China and even lead to structural changes. Therefore, the bootstrap rolling window that we use to investigate the relationship between IRD and SCF is reasonable, which considers the specific backgrounds and obtains a more accurate relationship with China. Based on this, the PBOC is able to make moderate monetary policies, give full play to its functions, and reduce the negative influence from SCF fluctuation. 


\section{Conclusions}

This study investigates the causal relationship between IRD and SCF using a bootstrap full-sample Granger-causality test and sub-sample rolling windowcausality estimation in China. In terms of the previous discussion we can conclude the results from empirical analysis mostly confirm our main hypothesis. First, the full-sample Granger causality test provides a unidirectional positive influence from IRD to SCF. Nevertheless, taking into consideration the presence of structural changes in the full-sample data, parameter stability tests find that in the short run, relationships between IRD and SCF are unstable. Second, we employ the approach of the bootstrap subsample and find IRD has both positive and negative on SCF and the Mundell-Fleming model only fits for China in some sub-periods. Although the relationship between IRD and SCF in China is not stable over time and even exhibits short-run deviations from the positive link, it actually fits well with the fact that that China experiences economic transition and structural changes in economic policies. The PBOC adopt discretionary policy that according to the economic environment regulating SCF and achieve various economic goals. In normal economic circumstances without internal and external shocks, IRD can lead to SCF. Otherwise, IRD cannot be attributed to the main reason that causes SCF. This provides some implications for the Chinese government, such as, the PBOC cannot simply implement low interest rate policy to curb the fluctuation of SCF during the recession, and to keep a reasonable and stable interest rate level in China for reducing speculation. The main limitations of this study are followings. On the one hand, China still carries out the conditional supervision for capital account and short-term capital inflows and outflows are restricted, on the other hand, Chinese process of interest rate liberalization has not completed, which means the interest rate cannot fully reflect the cost of capital. The future research is focus on the liberalization process of capital account and interest rate, and concerns about the relevant government policies.

\section{References}

Ahmed, S., Zlate, A. (2014) "Capital flows to emerging market economies: A brave new world?" Journal of International Money and Finance, Vol. 48, pp. 221248, doi: 10.1016/j.jimonfin.2014.05.015.

Andrews, D. W. K. (1993) "Test for Parameter Instability and Structural Change with Unknown Change Point", Econometrica, Vol. 61, No. 4, pp. 821-856, doi: $10.2307 / 2951764$.

Andrews, D. W. K., Ploberger, W. (1994) "Optimal Test when a Nuisance Parameter is Present only under the Alternative", Econometrica, Vol. 62, No. 6, pp. 13831414, doi: $10.2307 / 2951753$. 
Ayanou, T. (2016) "Foreign capital inflows to the USA and mortgage interest rates", Journal of Housing Economics, Vol. 34, pp. 1-14, doi: 10.1016/j.jhe.2016.06.001.

Aizenman, J., Hutchison, M. M. (2012) "Exchange market pressure and absorption by international reserves: Emerging markets and fear of reserve loss during the 2008-2009 crisis", Vol. 31, No. 5, pp. 1076-1091, doi: 10.1016/j.jimonfin. 2011.12.011.

Balcilar, M., Ozdemir, Z. A., Arslanturk, Y. (2010) "Economic Growth and Energy Consumption Casual Nexus Viewed through a Bootstrap Rolling Window", Energy Economics, Vol. 32, No. 6, pp. 1398-1410, doi: 10.1016/j.eneco.2010.05.015.

Balcilar, M., Ozdemir, Z. A. (2013) "The Export-Output Growth Nexus in Japan: A Bootstrap Rolling Window Approach”, Energy Economics, Vol. 44, No. 2, pp. 639-660, doi: 10.1007/s00181-012-0562-8.

Carvalho, D., Fidora, M. (2015) "Capital inflows and euro area long-term interest rates", Journal of International Money and Finance, Vol. 54, pp. 186-204, doi: 10.1016/j.jimonfin.2015.02.021.

Chari, V. V., Kehoe, P. J. (2003) "Hot Money”, Journal of Political Economy, Vol. 111, No. 6, pp. 1262-1292, doi: 10.1086/378525.

Cheung, Y., Steinkamp, S., Westermann, F. (2016) "China's capital flight: Pre- and post-crisis experiences", Journal of International Money and Finance, Vol. 66, pp. 88-112, doi: 10.1016/j.jimonfin.2015.12.009.

Fleming, J. M. (1962) "Domestic financial policies under fixed and floating exchange rates”, IMF Staff Paper, Vol. 9, No. 3, pp. 369-380, doi: 10.2307/3866091.

Hacker, R. S., Karlsson, H. K., Mansson, K. (2014) "An investigation of the causal relations between exchange rates and interest rate differentials using wavelets", International Review of Economics and Finance, Vol. 29, pp. 321-329, doi: 10.1016/j.iref.2013.06.004.

Hansen, B. E. (1992) "Tests for Parameter Instability in Regression with I(1) Processes", Journal of Business and Economic Statistics, Vol. 10, No.1, pp. 321-336, doi: 10.1198/073500102753410381.

Hu, K. (2013) "Study of Capital Flows Effect on Regional Economic Development", Informatics and Management Science VI, Vol. 209, pp. 387-392, doi: 10.1007/978-1-4471-4805-0_46.

Gardner, L. A. (1969) "On Detecting Changes in the Mean of Normal Variates", The Annals of Mathematical Statistics, Vol. 40, No. 1, pp. 116-126, doi: 10.1214/aoms/1177697808.

Globan, T. (2015) "Financial integration, push factors and volatility of capital flows: evidence from EU new member states", Empirica, Vol. 42, No. 3, pp. 643-672, doi: 10.1007/s10663-014-9270-2.

Glick, R., Hutchison, M. (2009) "Navigating the trilemma: Capital flows and monetary policy in China", Journal of Asian Economics, Vol. 20, No. 3, pp. 205-224, doi: 10.1016/j.asieco.2009.02.011. 
Gu, R., Chen, X., Li, X. (2014) "Chaos recognition and fractal analysis in the term structure of Shanghai Interbank Offered Rate", Physica A, Vol. 412, pp. 101112, doi: 10.1016/j.physa.2014.06.036.

Kim, J. (2007) "Real exchange rates and real interest rate differentials for sectoral data: A dynamic SUR approach", Economics Letters, Vol. 97, No. 3, pp. 247252, doi: 10.1016/j.econlet.2007.03.011.

Kumhof, M. (2004) "Sterilization of short-term capital inflows-through lower interest rates?", Journal of International Money and Finance, Vol. 23, No. 7, pp. 1209-1221, doi : 10.1016/j.jimonfin.2004.07.001.

Makhetha-Kosi, P., Mishi, S., Ngonyama, N. (2016) "The Response of Capital Flows to Interest Rate Differentials: The Case of South Africa", Journal of Economics, Vol. 7, No. 2, pp. 119-129, doi: 10.1080/09765239.2016.11907827.

Mensi, W., Hammoudeh, S., Nguyen, D. K., Kang, S. H. (2016) “Global financial crisis and spillover effects among the U.S. and BRICS stock markets", International Review of Economics and Finance, Vol. 42, pp. 257-276, doi: 10.1016/j.iref.2015.11.005.

Mundell, R. A. (1960) "The monetary dynamics of international adjustment under fixed and flexible exchange rates", Quarterly Journal of Economics, Vol. 84, No. 2, pp. 227-257, doi: 10.2307/1884252.

Ning, Y., Wang, Y., Yang, Z., Geng, Y. (2017) "Measurement and multifractal properties of short-term international capital flow in China", Physica A: Statistical Mechanics and its Applications, Vol. 468, pp. 714-721, doi: 10.1016/j.physa.2016.10.063.

Nyblom, J. (1989) "Testing for the Constancy of Parameters over Time", Journal of the American Statistical Association, Vol. 84, No. 405, pp. 223-230, doi: 10.1080/01621459.1989.10478759.

Ogawa, E., Wang. Z. (2016) "Effects of Quantitative Easing Monetary Policy Exit Strategy on East Asian Currencies", The Developing Economies, Vol 54, No. 1, pp. 103-129, doi: 10.1111/deve.12099.

Pesaran, M. H., Timmermann, A. (2005) "Small Sample Properties of Forecasts from Autoregressive Models under Structural Breaks", Journal of Econometrics, Vol. 129, No. 1, pp. 183-217, doi: 10.1016/j.jeconom.2004.09.007.

Shukur, G., Mantalos, P. (2004) "Size and Power of the RESET Test as Applied to Systems of Equations: A Bootstrap Approach", Journal of Modern Applied Statistical Methods, Vol. 3, No. 2, pp. 370-385, doi: 10.22237/jmasm/1099267800.

Shukur, G., Mantalos, P. (2000) "A Simple Investigation of the Granger-Causality Test in Integrated-Cointegrated VAR Systems", Journal of Applied Statistics, Vol. 27, No. 28, pp. 1021-1031, doi: 10.1080/02664760050173346.

Tamakoshi, G., Hamori, S. (2014) "On cross-currency transmissions between US dollar and euro LIBOR-OIS spreads", Research in International Business and Finance, Vol. 30, pp. 83-90, doi: 10.1016/j.ribaf.2013.06.001. 
Wang, C., Hwang, J., Chung, C. (2016). "Do short-term international capital inflows drive China's asset market?", The Quarterly Review of Economics and Finance, Vol. 60, pp. 115-124, doi: 10.1016/j.qref.2015.10.006.

Zeileis, A., Leisch, F., Hornik K., Kleiber, C., Hornik, K. (2005) "Monitoring structural change in dynamic econometric models", Journal of Applied Econometrics, Vol. 20, No. 1, pp. 99-121, doi: 10.1002/jae.776.

\title{
Je li Mundell-Flemingov model primjenjiv u Kini?
}

\author{
Kai-Hua Wang ${ }^{1}$, Chi-Wei $\mathrm{Su}^{2}$, Ran Tao ${ }^{3}$
}

\begin{abstract}
Sažetak
Ovaj rad ispituje uzročnu vezu između diferencijalne kamatne stope (IRD) $i$ međunarodnog kratkoročnog tijeka kapitala (SCF) kako bi se utvrdilo podržava li takav odnos Mundell-Flemingov model u Kini. Proučavajući postojeće strukturne promjene, ustanovili smo da je dugoročni odnos koji koristi podatke iz cijelog uzorka nestabilan, što sugerira da test uzročnosti nije pouzdan. Slijedom toga, koristimo model pomičnih prosjeka vremenskih serija kako bismo preispitali dinamičku uzročnu vezu, a rezultati pokazuju da diferencijalne kamatne stope (IRD) imaju pozitivan i negativan utjecaj na kratkoročni tijek kapitala (SCF) u nekoliko podrazdoblja, ali SCF ne utječe na IRD u Kini. Prolazeći kroz vanjske i unutarnje šokove, Kina ne bi trebala kratkoročni tijek kapitala (SCF) ograničavati samo na prilagodbu diferencijalne kamatne stope (IRD). Stoga je ključno da donositelji / kreatori politike obrate pozornost na specifične okolnosti (npr. ekonomsku situaciju, monetarnu politiku) te da i dalje primjenjuju kamatnu i fiskalnu politiku kako bi se reducirao negativni utjecaj SCF-a na kinesko gospodarstvo.
\end{abstract}

Ključne riječi: Mundell-Fleming model, kratkoročni tijek kapitala, diferencijalna kamatna stopa, pomični prosjek vremenskih serija, kauzalnost pomičnog prosjeka vremenskih serija

JEL klasifikacija: C32, F32, G18

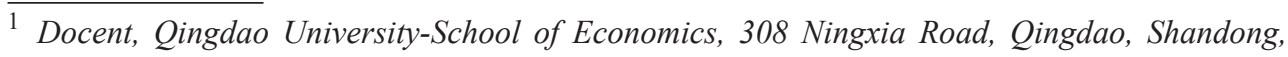
Kina. Znanstveni interes: međunarodne financije $i$ upravljanje rizicima. Tel.: +86 15762285927.E-mail:937276847@qq.com.

2 Redoviti profesor, Qingdao University-School of Economics, No. 308 Ningxia Road, Qingdao, Shandong, Kina. Znanstveni interes: analiza vremenskih serija, međunarodne financije $i$ upravljanje rizicima. Tel.: +86 18661491158.E-mail: cwsu7137@gmail.com (osoba za kontakt).

3 Inženjer, Technological Center, Shandong Entry-Exit Inspection and Quarantine Bureau, No. 6 Yiling Road, Qingdao, Shandong, Kina. Znanstveni interes: međunarodne financije i ekonomsko modeliranje.Tel.: +86 15165252618.E-mail: taotao0212@163.com. 